\title{
Economic Diversification by Boosting Non-Oil Exports (Case of UAE)
}

\author{
M. Hazem Shayah
}

\begin{abstract}
UAE, the world's eighth biggest oil producer, maintains a free-market economy with minimum restrictions on private-sector activities, international trade and capital movements. In spite of the impact of the global economic recession, the UAE's economy has proved to be remarkably flexible. In this paper we will see that UAE Economy is one of the most diversified economies between the Arab countries because it's not just relying on oil, it has also so many important sectors which play a big role in the Economic development of the country like Trade and tourism, and in this paper we will see the role of non-oil Exports in the Economic diversification.
\end{abstract}

Index Terms-Economic diversification, non-oil exports, trade, UAE.

\section{INTRODUCTION}

The United Arab Emirates (UAE) is the centre for international business in the Gulf region with strong international trade status and huge state-owned investment fund invested in real and financial assets.

Higher oil prices, increased government spending and a notable resurgence in tourism, transport and trade have contributed to the upswing in the economy. Additionally, the successful restructuring of debt owed by high-profile companies, harmony among the emirates and accommodative monetary and fiscal policies have all played a role in bringing stability to the market. Political confusion in the Middle East and North Africa has not impacted negatively on the UAE's economic growth since it is considered to be one of the most politically stable and secure countries in the area and relatively safe place for tourism and investment.

The United Arab Emirates is a federation of seven monarchies: Abu Dhabi, Ajman, Dubai, Fujairah, Ras Al-Khaimah, Sharjah, and Umm al-Qaiwain. The government has done some reform during the 2011 by initiating a $\$ 1.6$ billion program to improve the infrastructure in the poorer northern emirates. Abu Dhabi accounts for about 90 percent of oil production; Dubai is the center of finance, commerce, transportation, and tourism. Free trade zones that permit 100 percent foreign ownership with zero taxation help to diversify the economy, but UAE nationals rely heavily on public-sector employment and subsidized services. Hydrocarbons account for roughly 80 percent of total government revenues.

In February 2010, the UAE launched its Vision 2021.This plan was preceded by the National Work Program from 2005,

Manuscript received December 18, 2013; revised February 21, 2014.

M. Hazem Shayah is with the School of Economics, Wuhan University of Technology, Wuhan, Hubei, China (e-mail: mhsh85@ hotmail.com). in addition to the UAE Government Strategy (2008-2010). Following the launch of Vision 2021, the government published the UAE Government Strategy (2011-2013).

\section{CONCEPT OF ECONOMIC DIVERSIFICATION}

Economic diversification is when the country has incomes from many different sources that are not directly related to each other. A good example of a poorly diversified economy is that of Saudi Arabia. A very large part of their income depends on the production and sale of oil to other countries, which means that their standard of living sometimes fluctuates wildly in correlation with the price of oil. South Korea economy is a good example of a better diversified economy. Because South Korea gets its income from many different types of economic activity including: manufacturing, automobile, Hi tech industries, and financial services.

In general economic diversification is taken as the process in which a growing range of economic outputs is produced. It could also refer to the diversification of markets for exports or the diversification of income sources away from domestic economic activities (i.e. income from overseas investment).

Economic diversification in its standard usage, either in terms of the diversity of economic activities or markets, is a significant issue for many developing countries, as their economies are generally characterized by the lack of it. They have usually relies heavily on the production of primary commodities that are mostly vulnerable to climate change.

So we can say that the Middle East's reliance on oil for its wealth is the main issue which makes Diversification for this region is a highly desirable aim, but how can it be achieved? One key requirement is innovation, which is why governments in the region have started different initiatives to foster innovation, with varying levels of success.

There are some barriers to growth in GCC countries which are envisioned in the plans and we think diversification can play a leading role in overcoming them, some of these barriers are:

- The future depletion of the hydrocarbon reserves.

- The second is the fluctuating price of oil.

- Third is the current economic model, the allocation state model.

- Fourth, there are the future difficulties of securing high living standards for the population, since the governments in all the states, with the possible exception of Qatar, do not have the financial means to act as the sole sponsor of the vast-welfare societies established over the last century.

Diversification is seen as a means to solve all of the above 
problems, or barriers to growth. In all the plans, diversification is understood as vertical diversification, where the crude output from the hydrocarbon sector is either processed into downstream products like petrochemicals or used an input into the manufacturing sector, such as in aluminum smelting or steel production. In both cases the value added benefits the country. Second, vertical diversification entails the growth of non-oil related manufacturing and especially service industries [1].

As a result, we can say that Economic diversification is so important for GCC countries and in particular the UAE. Recently GCC countries have taken some steps in achieving economic diversification.

UAE was the most competitive economy in the Middle East, more than many of the developed countries, according to IMD World Competitiveness Centre Index (2013). The index ranked the emirate as the 8th most competitive economy in the world, more competitive than France (28), Japan (24), Australia (16), Spain (45), Portugal (46), and Russia (42). IMD rated Canada just one notch above the UAE ranking it 7th most competitive economy globally [2]. Official figures have showed that Abu Dhabi and Dubai have been investing billions of dollars to diversify their economies in order to diminish reliance on oil and petrochemical sectors. Both the emirates are pumping money into trade, tourism, logistics, aviation, infrastructure and banking and finance

The member countries of the Gulf cooperation council (GCC) passed major economic transformation over the past decade. The main goal of the economic policies set into place was to diversify their economies away from the oil sector. This long standing problem is linked to the non-renewable nature of oil resources. The instability of oil revenues combined with strong demographic expansion have brought the topic back into the headlines especially after the new rules regarding labor force in GCC countries and the need to create jobs, all of these factors lead to start the new polices like Emiratization which is a government policy designed to increase the participation of native workers in the production of goods and services in the UAE private sector. The policy has its origins in the 1990s out of government's concerns of private sector's heavy reliance on expatriate labor, high unemployment among native workers and the expectation of a relatively young Emirati population entering the labor force by the mid 2010s. It is estimated that in the next ten years, 200,000 young Emirati nationals (or 25 percent of the current Emirati population) will be entering the labor force [3].

\section{UAE ECONOMY}

\section{A. Introduction}

The UAE has an open economy with a high per capita income and a great annual trade surplus. Successful efforts at economic diversification have reduced the portion of GDP based on oil and gas output to $25 \%$. Since the discovery of oil in the UAE more than 30 years ago, the country has undergone a deep transformation from a poor region of small desert principalities to a modern state with a high standard of living. Like The Infrastructure in the UAE is really well developed following a period of rapid growth that saw the construction of residential, tourism, industrial and commercial facilities on a huge scale, because of that the UAE has become a major market for Chinese construction contracts in the Gulf region. The realized revenue of construction contracts for Chinese companies in the UAE soared from $\$ 55.16$ million in 2001 to $\$ 3.62$ billion in 2009[4].Lately the global financial crisis, reduced international credit, and discouraged asset prices constricted the economy in 2009. UAE authorities tried to solve the crisis by more government spending and boosting liquidity in the financial sector. The crisis hit Dubai hardest, as it was heavily exposed to depressed real estate prices. Dubai lacked enough cash to meet its debt obligations. The UAE Central Bank and Abu Dhabi-based banks bought the largest shares. In December 2009 Dubai received an additional $\$ 10$ billion loan from the emirate of Abu Dhabi.

\section{B. Oil Sector in $U A E$}

Even though the relative contribution of the different economic sectors to GDP have shifted obviously over the years, the oil and gas sector has represented the largest share in the UAE, since the country is endowed with huge resources of oil and gas. The UAE possesses nearly $10 \%$ of the world's total reserves, and there is no doubt that oil will continue to provide the income for both economic growth and the expansion of social services for several more decades at least. Oil production is around two million barrels a day. Gas is increasingly important, both for export, and for meeting local demand, from domestic and industrial consumers and for power generation and water desalination plants. Over the years, the federation has been a strong supporter of OPEC and has generally adhered to its quota, even though the situation has meant that Abu Dhabi has had to produce well below its actual production capability [5].

\section{Balance of Payment}

According to the UAE Central Bank, high oil prices and the performance of non-hydrocarbon exports were the drives behind an increase in the trade account surplus from Dh154.6 billion in 2009 to Dh179.9 billion in 2010 and Dh292 billion in 2011(one USD is about 3.67 AED). The balance of services and transfers, are traditionally negative in the UAE (i.e. the related flows of funds leaving the country are higher in value than the flows coming in) and as a result the current account surplus was much lower than that of the trade balance in these years, reaching Dh28.8 billion in 2009, Dh26.6 billion in 2010 and Dh112.7 billion in 2011[6].

\section{Boosting Non-Oil Exports}

United Arab Emirates (UAE) has got special particularity in regards of investment environment from the prospective of politics, policy, regulation, investment barriers, and restrictions. Foreign investors in the United Arab Emirates enjoy a set of substantial incentives and benefit from first-rate transport and communication infrastructures. The United Arab Emirates grants 100\% ownership to foreign investors in its free zones, does not levy taxes, and dispenses with restrictions on the transfer of capital to and from the country. In addition, the cost of gas and electricity is moderate and the exchange rate of the national currency, the dirham, against the United States 
dollar has been stable since 1980 [7].The World Trade Organization (WTO) ranked the UAE as the world's twentieth biggest exporter of merchandise trade in 2011, surpassing countries such as Australia, Brazil, Switzerland and Sweden. According to the WTO, the UAE's exports of US\$285 billion (Dh1.045 trillion) in merchandise trade in that year amounted to 1.6 per cent of the world's exports, which stood at US\$18.215 trillion. The WTO also lists the UAE as the world's twenty-fifth importer based on UAE imports of Dh752.35 billion (US\$205 billion) in 2011, 1.1 per cent of the world's imports of US\$18.38 trillion. Continued growth in trade is the result of the UAE's determined policies of opening new markets, engaging new trade partners and increasing economic diversification. Fig. 1 released by the UAE National Bureau of Statistics highlight that in the first nine months of 2012 non-oil trade increased from Dh684.9 billion in the same period in 2011 to Dh782.7 billion in 2012, up 10.5 per cent. Exports were up by 61 per cent from Dh84.4 billion to Dh136.6 billion and imports rose by 12.3 per cent (from Dh439.9 billion to Dh494.5 billion) in the same period. The Value of the re-exports dropped by 5 per cent to Dh152.6 billion. Non-Arab Asian countries (45 per cent), maintained their position as leading partners in UAE non-oil trade, the EU came second (23 per cent), America was ranked third ( 9.3 per cent) and the GCC fourth (8 per cent).

Gold tops both the import and exports with diamonds leading re-exports. Other significant exports are polyethylene, polypropylene and crude aluminum. So many studies by the Ministry of Foreign Trade highlight the significant role of plastics in UAE trade. According to the report, the UAE came third globally in the re-export of plastics in 2011, re-exporting US\$444 million worth of the product constituting a 3 per cent share of the worlds re-exports of plastics. One of the studies indicates that exports of plastics from the UAE increased by 127 per cent (US $\$ 2.2$ billion) from the first six months of 2011 to the same period in 2012. Regionally, the study stated that the UAE produces 25 per cent of all plastics produced within the Gulf Cooperation Council (GCC), pointing out that the country has over 600 plastics factories spread out across the seven emirates and through the huge Free Zones. For example of the Free Zones in UAE we have Jebel Ali Free Zone, Dubai Airport Free Zone (DAFZ), Ras Al Khaimah Free Trade Zone, and Dubai Industrial City (DIC).

Borouge, one of the largest plastics factories in UAE, is expected to produce 2.5 million tons of plastics in 2014 from the current capacity of just over 2 million tons.

After reaching a peak of 210.0 billion US\$ in 2008, the value of the exports of United Arab Emirates contracted sharply by 16.8 percent in 2009 but increased again in 2010 by 13.5 percent to amount to 198.4 billion US\$. Imports increased by 10.0 percent in 2010 to 180.7 billion US\$. The trade surplus went up to 17.6 billion US\$ in 2010 from 10.5 billion US\$ in 2009.During the years preceding the global economic crisis the UAE's economy was performing fairly well. The United Arab Emirates GDP Growth Rate reached an all time high of 9.8 percent in 2006. While in the next two years (2007 and 2008) the pace of growth has diminished to 3.2 percent at constant prices. The Non Oil sector experienced a higher rate of growth of 9.3 percent in 2007 and a good 6.0 percent in 2008. Conversely, the global crisis has severely hit the UAE economy, so the GDP contracted of 4.8 percent at constant prices in 2009 , led by a remarkable fall in manufacturing, but also in real estate. The year of the crisis, i.e. 2009, hit more heavily the economy on the whole than the Non Oil sector, which experienced a decrease of 2.9 percent. But the manufacturing industries have particularly suffered with a decrease of 14.1 percent. However, the economy regained confidence after the crisis. In 2010 the growth of GDP was a respectable 1.3 percent at constant prices [8].

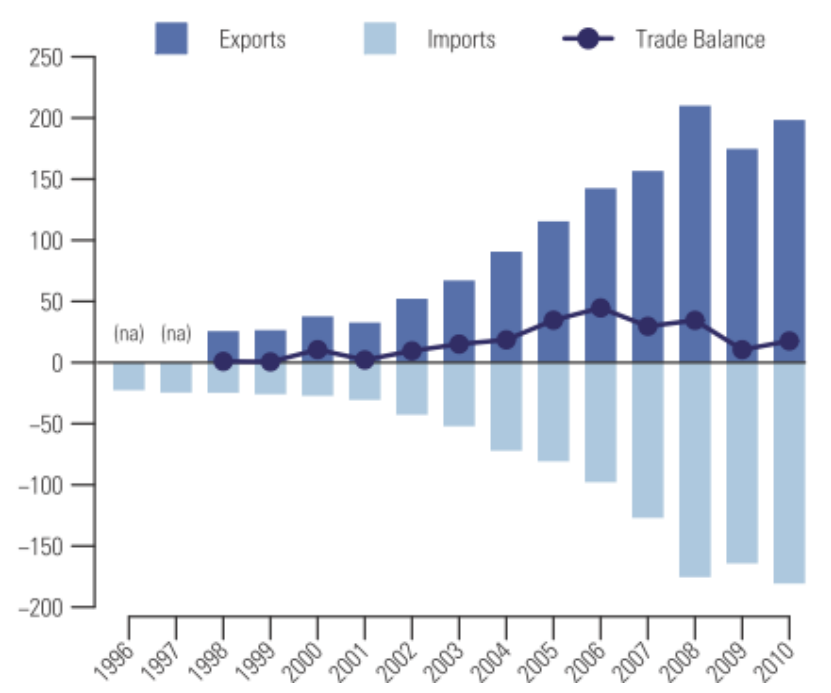

Fig. 1. Total imports, exports and trade balance (billion US\$ by year).

\section{DIVERSIFICATION IN UAE}

Diversification is so important to promote development, and create job opportunities. However, this growth must not come at the expense of stability. So Inflation, fiscal balance and other Economic levels must be ensured. , policy makers must make sure about their ability to drive the economy in order to reduce reliance on foreign companies and workers. In general we can say that an increased economic diversification can improve the performance of the economy and reduce volatility. Dubai has been the most proactive and eager emirate in its attempt at diversification in the GCC region. Through a historical commitment to a business-friendly environment, with openness towards foreigners in business and in society in general, as well as a strong belief in the proactive role of the 'state' in the economy. The key elements of the 'Dubai model' of economic development are the following: 1) government-led development, 2) fast decision making 'fast-track' development, 3) a flexible labor force through importing expatriates, 4) by passing industrialization and creating a service economy, 5) internationalizing service provision, 6) creating investment opportunities, 7) supply-generated demand, 8) market positioning via branding, and 9) development in cooperation with international partners [9]. after all what we have seen, we can say that exporting and reexporting has played a huge role in promoting and maintaining the process of economic diversification by adding value of the non-oil GDP, in Table I we can see trade 
data of the years (2005-2011).

TABLE I: UAE TRADE DATA

\begin{tabular}{|l|l|l|l|l|l|l|}
\hline \multirow{2}{*}{ YEAR } & \multicolumn{2}{|c|}{ IMPORTS } & \multicolumn{2}{c|}{ NON-OIL EXPORTS } & \multicolumn{3}{c|}{ RE-EXPORTS } \\
\cline { 2 - 8 } & WEIGHT (In KG) & VALUE (In AED) & WEIGHT (IN KG) & VALUE (In AED) & WEIGHT (In KG) & VALUE (In AED) \\
\hline 2005 & $46,551,574,131$ & $247,589,715,083$ & $19,777,449,641$ & $16,462,607,861$ & $7,695,398,517$ & $97,043,197,533$ \\
\hline 2006 & $48,854,525,569$ & $291,048,964,687$ & $68,646,135,709$ & $29,232,285,857$ & $8,944,782,694$ & $95,580,167,401$ \\
\hline 2007 & $56,039,666,989$ & $388,356,836,394$ & $41,732,706,035$ & $36,262,324,842$ & $8,934,934,038$ & $128,338,414,920$ \\
\hline 2008 & $62,469,851,769$ & $565,719,823,370$ & $35,137,024,727$ & $60,359,055,129$ & $9,328,003,555$ & $162,844,575,681$ \\
\hline 2009 & $49,047,871,441$ & $447,393,840,482$ & $22,389,227,100$ & $65,278,896,534$ & $8,839,731,000$ & $147,693,366,837$ \\
\hline 2010 & $47,720,694,580$ & $485,413,921,746$ & $19,892,372,520$ & $83,077,687,323$ & $8,733,199,965$ & $185,863,253,742$ \\
\hline 2011 & $52,216,661,963$ & $602,757,314,852$ & $24,326,946,906$ & $114,038,287,878$ & $8,553,466,009$ & $210,842,814,591$ \\
\hline
\end{tabular}

Source: National Bureau of Statistics UAE

\section{CONCLUSION}

UAE economy regained confidence after the crisis because of the high diversification of the Economy. But we think that UAE's economy to become more diversified and competitive it must has new companies those are, radical innovators able of integrating heterogeneous technologies and using the best scientific and technological research, but also should produce and export different kinds of products and not just rely on the oil sector. But also we can say that continued growth in trade can be attributed to the UAE's determined policies of opening new markets, engaging new trade partners and increasing economic diversification which I think it can continue in $\mathrm{UAE}$ in the coming years.

\section{REFERENCES}

[1] M. Hvidt, "Economic diversification in GCC countries: Past record and future trends," Research Paper. Kuwait Programme on Development, Governance and Globalisation in the Gulf States, vol. 27, pp. 34-35, January 2013.

[2] IMD, World Competitiveness Yearbook 2013, International Institute for Management Development, IMD, 2013.

[3] H. Toledo, "The political economy of emiratization in the UAE," Journal of Economic Studies, vol. 40, no. 1, pp. 39-53, 2013.

[4] C. Mo, "Exploring Economic Relations between China and the GCC States," Journal of Middle Eastern and Islamic Studies, in Asia, vol. 5, no. 4, pp. 88-105, 2011.
[5] O. Masood and B. S. Sergi, "Quantitative measurement of economic sectors effect on the non-oil GDP in United Arab Emirates," International Journal of Trade and Global Markets, vol. 1, no. 3, pp. 239-258, 2008.

[6] National Bureau of Statistics UAE. [Online]. Available: http://www.uaestatistics.gov.ae

[7] A. Safi. (March 28, 2012). Direct Investment in the Arab World: An Analysis of Flows and an Evaluation of Country Specific Business Environment. SSRN working papers. [Online]. Available: http://ssrn.com/abstract=2045631

[8] D. Schilirò. (May 2013). Diversification and development of the UAE's economy. MPRA Paper, University Library of Munich, Germany. [Online]. Available: http://mpra.ub.uni-muenchen.de/47089/

[9] M. Hvidt, "The Dubai model: an outline of key development-process elements in Dubai," International Journal of Middle East Studies, vol. 41, no. 3, pp. 397-418, 2009.

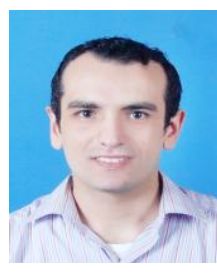

M. Hazem Shayah was born in Aleppo, Syria in 1985. $\mathrm{He}$ received the bachelor degree in business administration from University of Aleppo, Aleppo, Syria, in 2007, and the master degree in international trade from Wuhan University of Technology, Wuhan, China in 2012.Currently he is a Ph.D. candidate in School of Economics at Wuhan University of Technology. His current research interests include trade liberalization, export growth, international business, emerging economies and economic development. 